\title{
Aplikasi Pemikiran Islam Dalam Pendidikan Sains
}

\author{
The Application of Islamic Thought in the Teaching of Science
}

\author{
Hamdi Rahman, M.Y. (Pengarang Penghubung) \\ Akademi Pengajian Islam Kontemporari, Universiti Teknologi MARA Cawangan Perak, \\ 32610 Bandar Baru Seri Iskandar, Perak, Malaysia \\ Tel: +6013-5848779 E-mel: hamdi105@perak.uitm.edu.my \\ Sofian Sauri, H \\ Fakulti Pengajian Islam, Universiti Sultan Azlan Shah Bukit Chandan, \\ 33000 Kuala Kangsar, Perak, Malaysia \\ Tel: +6019-7558595 E-mel: sofian@usas.edu.my \\ Mohd Zahirwan Halim, Z.A. \\ Akademi Pengajian Islam Kontemporari, Universiti Teknologi MARA Cawangan Perak, \\ 32610 Bandar Baru Seri Iskandar, Perak, Malaysia \\ Tel: +6019-2677081 E-mel: mohdz560@perak.uitm.edu.my \\ Paiz Hassan. \\ Akademi Pengajian Islam Kontemporari, Universiti Teknologi MARA Cawangan Perak, \\ 32610 Bandar Baru Seri Iskandar, Perak, Malaysia \\ Tel: +6019-6673578 Emel:paiz4186@perak.uitm.edu.my \\ Muhammad Yusri, Y.S. \\ Akademi Pengajian Islam Kontemporari, Universiti Teknologi MARA Cawangan Perak, \\ 32610 Bandar Baru Seri Iskandar, Perak, Malaysia \\ Tel: +6019-4495027 E-mel: yusri613@perak.uitm.edu.my
}

\begin{abstract}
Abstrak
Penulisan ini bertujuan memperjelaskan peranan pemikiran Islam dalam pendidikan Sains ke arah melahirkan saintis berjiwa ululalbab bertaraf ulama sebagaimana firman Allah (s.w.t) "Sesungguhnya mereka yang takutkan Allah di kalangan hambaNya ialah ulama" Al Quran (35:28). Fokus penulisan akan membicarakan konsep ulama serta menjelaskan kedudukan saintis Islam yang berusaha menyelidiki hukum alam demi kebaikan dunia dalam masa yang sama menjadikannya sebagai mekanisma mengenali Tuhan dan keagunganNya dan hubungan mereka dengan istilah tersebut. Ia juga akan memperjelaskan aplikasi proses tafakkur Islam di mana penyelidikan saintifik merupakan sebahagian daripada peringkat bertafakkur dengan objektif memahami rahsia
\end{abstract}

dan keindahan alam ke arah menghayati keagungan dan kesempurnaan Allah (s.w.t) dalam setiap penemuan tersebut. Penulisan ini juga akan menyentuh bagaimana penyelidikan saintifik menemui kewujudan dan keesaan Allah serta kebenaran Baginda Muhammad (s.a.w)

Kata Kunci: Pemikiran Islam; Sains, Ulama; Ulul Albab; Pengajian Sains

\begin{abstract}
This paper intends to explain and deliberate on the role of Islamic thought in the teaching of science in the hope of inspiring scientists who will truly be imbued with the spirit and quality of "ulul' albab", the way Allah swt declares, "... Verily, those who fear Allah among His servants are the people of knowledge ...," (Qur'an, 35:
\end{abstract}


28). This paper delves on the qur'anic meaning of 'ulama' ('people of knowledge'), and explains the position of Muslim scientists who explore and investigate the laws of nature all for the sake and betterment of the world, while at the same time utilizing their investigation of nature to conceive and glorify God. It is also intended to illuminate on the nature and need to reflect in Islam such that the scientific effort to investigate and understand nature is in essence an act of mental and spiritual reflection that is much encouraged as a process and an expression of the human attempt to appreciate and internalize the majesty, greatness and supremacy of God that are ever present in every scientific discovery. Finally, this paper attempts to demonstrate how a scientific effort and investigation actually leads to the realization of the existence and the unity of God, as well as the truth about Muhammad, the Prophet of Islam.

Keywords: Islamic Thought; Science; Ulama; Ulul Albab; Teaching Science

\section{Sejarah Perhubungan Antara Sains Dan Wahyu}

Perkembangan pengetahuan manusia mengenai tatacara serta bentuk ketaatan dan ketundukan alam tabii kepada sunnah Allah atau apa yang diistilahkan hari ini sebagai sains tabii, begitu juga eksploitasi manusia terhadap ketaatan dan ketundukan tersebut untuk kegunaan mereka dalam bentuk teknologi, sebenarnya telah melewati fasa zaman yang panjang. Melihat kepada historiografi sains Islam, bermula dari zaman Adam ((a.s)), dan kemudiannya berpindah dari satu tamadun ke satu tamadun yang lain, sains dan teknologi mempunyai hubungan yang cukup erat dengan nilai-nilai metafizik ajaran tawhid, sebelum ianya dipisahkan oleh kecemburuan kebangkitan renaissance barat melalui penerapan ideologi sekular pilihan tabii Darwin.

Bermula dengan Adam (a.s), Al-Quran merakamkan secara jelas bahawa Allah S.W.T telah mengajarnya segala sifat dan ciri-ciri bagi hakikat setiap perkara (al-Razi, 2000), dan ini menunjukkan baginda mempunyai pengetahuan luas berhubung sains tabii.

Dalam tradisi sains heramatik pula Idris (a.s) merupakan hermes pertama (al-Alusi, 2000; Kevin Van Bladel, 2009) yang dikenali sebagai al-Muthallathah bi al-Hikmah atau alMuthallath bi al-Ni 'mah (thrice wise) yang dikenali di Yunani sebagai Hermes Trismegistus (Ibn al-Kindi, 2009; Kevin Van Bladel, 2009). Baginda merupakan orang pertama yang menggunakan tulisan serta mengajar sains kosmologi, dan perubatan kepada masyarakat manusia (al-Ya'qoobi, 2002). Begitu juga baginda dikatakan sebagai orang pertama yang memberi amaran berhubung kedatangan banjir besar serta mengarahkan pembinaan piramid di Mesir sebagai tempat simpanan harta dan dokumen ilmu pengetahuan di samping menjadikan dindingnya sebagai tempat catatan demi kesinambungan ilmu pengetahuan untuk generasi akan datang ('Abari, 2007). Menurut alSuyūti pelbagai ilmu termasuk kosmologi serta ilmu berkenaan kejadian yang berlaku di alam ini diajar secara turun temurun daripada Adam (a.s), melalui anaknya Shith (a.s) hinggalah kepada Idris. (a.s) (Alusi, 2000).

Manakala hermes kedua adalah al-Bābili, berbangsa Kaldaen (Chaldean) yang menetap di Babylon dan hidup selepas peristiwa banjir besar di zaman Nuh (a.s). (Ibn Abari, 2007; Ibn Abi Usaibi‘ah, 2016). Beliau bertindak memperbaharui ilmu-ilmu perubatan, falsafah dan metamatik di Babylon yang hilang selepas banjir (Ibn Abi Usaibi'ah, 2016), dan antara pelajarnya yang terkenal ialah Pitagoras (580 BC - 490 BC) (Ibn Abi Usaibi'ah, 2016). Hermes ketiga pula ialah seorang dari Mesir yang juga menetap di sana selepas banjir besar (Ibn Abari, 2007; Ibn Abi Usaibi'ah, 2016). Beliau juga seorang ahli perubatan dan ahli falsafah, serta mempunyai pengetahuan mendalam dalam bidang kimia yang menjadi asas kepada pembuatan seperti kaca, manik dan seramik (Ibn Abi Usaibi'ah, 2016). Antara pelajarnya yang terkenal ialah Asclepius (Ibn 
Abi Usaibi'ah, 2016) dan Thales (624 S.M - 546 S.M) (Hairudin Harun, 1992). Hubungan tradisi sains herematik dengan ahli falsafah Yunani ini boleh memperjelaskan pola perkaitan sains Yunani dengan tamadun awal yang telah terbina dalam kesepaduan ilmu dan agama.

Selain itu hubungan ahli falsafah Yunani dengan tamadun Israel Purba, yang menjadi tempat kelahiran berbilang rasul Bani Israel mampu memperkuatkan kesimpulan ini. Empedokal contohnya yang pernah menjadi pelajar kepada Nabi Daud (a.s) dan Luqman Hakim, memperkatakan berhubung keesaan tuhan dalam masyarakatnya di Yunani (alSyahrastani, 2013; Ibn Abi Usaibi'ah, 2016). Thales yang juga dikatakan mempunyai hubungan keilmuan dengan Luqman Hakim (Ibn Khaldun, 2001) pula mengasaskan falsafahnya yang memperakui bahawa alam mempunyai pencipta yang zatnya tidak mampu ditaakul akal manusia, namun boleh diperhati melalui hasil ciptaanya (al-Syahrastani, 2013). Pandangan beliau berkenaan kedudukan air sebagai asas kejadian (al-Syahrastani, 2013; Maqdisi, t.t.) pula dilihat bersamaan dengan ajaran kitab suci al-Taurat (al-Syahrastani, 2013) dan al-Quran. Pitagoras pelajar Thales (Ibn Khaldun, 2001) yang datang selepas itu, ketika beliau berada di Mesir bagi mendalami ilmu kejuruteraan berkesempatan mempelajari hikmah daripada sahabat-sahabat Nabi Sulaiman ketika mereka membuat lawatan ke sana, dan beliau berjaya membawa pulang sains tabii, kejuruteraan dan agama ke dalam tamadun Yunani (Ibn Khaldun, 2001; Ibn Abi Usaibi'ah, 2016). Socrates yang memperolehi ilmu melalui hasil Pitagoras, juga terkenal dengan sifat zuhud dan banyak membicarakan soal jiwa serta pembentukan akhlak dihukum bunuh oleh pemerintah zamannya. Beliau mati diracun selepas dipenjarakan kerana menyeru mereka kepada tuhan yang esa dan menegah mereka dari menyembah berhala (al-Syahrastani, 2013; Ibn Abi Usaibi'ah, 2016).

\section{Konsep Ulama Menurut Al-Quran}

Allah (s.w.t) telah befirman dan maksudnya "Bahawasanya hanyalah yang takut kepada Allah di kalangan hambaNya adalah ulama" Al Quran (35:28).

Susunan ayat mendahulukan objek kepada kata kerja 'takut' iaitu Allah daripada pelakunya iaitu ulama, bertujuan memperjelaskan siapakah mereka yang takut kepada Allah (Alusi, 2000). Ini membawa erti siapa yang takutkan Allah, dia semestinya seorang ulama, dan sebaliknya pula mereka yang bukan ulama tidak takutkan Allah (al-Andalusi, 1993; al-Baqqai, t.t.). Bagaimanapun petunjuk ayat ini tidak pula menafikan wujudnya golongan ulama yang tidak takut kepada Allah. Berhubung perkara ini Ibn Kathir (1999) menukilkan kata-kata Sufyan alThauri yang membahagikan ulama kepada tiga kolompok, getusnya: "Ulama ada tiga jenis, alim dengan Allah dan alim dengan suruhan Allah, alim dengan Allah tetapi tidak alim dengan suruhan Allah, alim dengan suruhan Allah tetapi tidak alim dengan Allah. Yang alim dengan Allah dan suruhannya ialah mereka yang takut kepada Allah dan mengetahui batas-batas dan kefarduan, dan yang alim dengan Allah tetapi tidak alim dengan suruhannya ialah mereka yang takutkan Allah tetapi tidak mengetahui batas-batas dan kefarduan, manakala yang alim dengan suruhan Allah tetapi tidak alim dengan Allah ialah mereka yang mengetahui batas-batas dan kefarduan tetapi tidak takut kepada Allah"

Justeru dapat diperhatikan bahawa terdapat dua kayu ukur dalam penentuan ulama, pertama sifat takut kepada Allah dan kedua kesarjanaan dalam bidang pengajian wahyu. Bagimanapun ketika membicarakan konsep ulama, para ulama lebih merujuk kepada sifat takutkan Allah (s.w.t) sebagai asas pengiktirafan berbanding nilai-nilai kesarjanaan mereka. Berhubung perkara ini Ibn Mas'ūd menjelaskan: "Ilmu bukanlah dengan banyak menghafal hadis, tetapi ilmu adalah dengan besarnya rasa takut" (Ibn Kathir, 1999). Al-Hasan al-Basri pula menyebut: "Orang alim ialah mereka yang takut kepada al-Rahmān 
dalam keadaan tidak boleh dilihat, suka dengan apa yang disukaiNya dan benci pada apa yang dibenciNya" (Ibn Kathir, 1999). Justeru walaupun tanpa kesarjanaan dalam bidang pengajian wahyu, seseorang yang mempunyai sifat takut yang tinggi padaNya hakikatnya adalah seorang ulama.

Menurut Ibn Abbas maksud ulama dalam ayat di atas ialah mereka yang benar-benar mengetahui bahawa Allah berkuasa di atas segala-galanya (al-Tabari, 1998; Ibn Kathir, 1999; al-Alusi, 2000). Ini kerana implikasi daripada ilmu tersebut, setelah memahami sifat kebesaran, keesaan dan keindahan Allah (s.w.t) akan mengalirkan perasaan mengagungkan Allah dalam diri seseorang individu, dan hasil interaksi dalaman dengan akalnya pula seterusnya akan menyemarakkan perasaan takut kepada Yang Maha Kuasa, justeru setiap pertambahan ilmu akan membawa kepada peningkatan tahap perasaan takut kepada Allah (s.wt.) (al-Andalusi, 1993; Ibn Kathir, 1998; al-Baqqai, t.t.).

Bagaimanapun bagi mencapai tahap keilmuan tersebut, hingga membawa kepada perasaan takutkan Allah secara konsisten dan menyeluruh, seseorang ulama di peringkat awal perlu membuktikan terlebih dahulu bahawa Allah (s.w.t) bersifat maha berkuasa serta memiliki segala sifa-sifat kesempurnaan. Berhubung dengan perkara ini Allah (s.w.t) mewujudkan ayat-ayatNya sebagai bahan bukti yang boleh dibaca, dikaji dan dihayati, sama ada bersifat wahyu langit iaitu al-Quran dan al-Sunnah ataupun makhluk ciptaanNya (Sayyid Qutb, 1998) di mana keajaiban keduanya mampu membawa pemerhati menemui pemiliknya. Di sini jika diwujudkan pengkhususan berasaskan bidang, maka fungsi penyelidikan bagi ayatayat jenis pertama boleh diberikan kepada ulama pengajian wahyu, manakala berhubung ayat-ayat jenis kedua diletakkan sebagai tanggungjawab ahli sains, di mana mereka juga merupakan ulama lantaran mengenali Allah dalam penyelidikan tersebut.
Rujukan kepada ayat 28 surah al-Fātir di atas, menunjukan ayat tersebut menyentuh keulamakan jenis kedua ini. Ini kerana berasaskan susunan ayatnya, penegasan ataupun kesimpulan 'hanya ulama sahaja yang takutkan Allah' merupakan kesinambungan daripada ayat-ayat saintifik sebelumnya (alBaqqai, t.t.) yang bersifat membangkitkan persoalan kepada manusia supaya berfikir untuk menemui kesempurnaan kekuasaan Allah serta keesaanNya dari kepelbagaian ciptaan yang melibatkan kategori (al-Razi, 2000) tumbuh-tumbuhan, benda dan haiwan, begitu juga dengan kepelbagaian warnanya (Sayyid Qutb, 1998; Ibn Kathir, 1999; al-Alusi, 2000). Sayyid Qutb (1998) dalam membicarakan ayat ini menjelaskannya dalam bahasa yang begitu indah, katanya: “...dan ulama ialah mereka yang memikirkan kitab [alam] yang penuh keajaiban ini. Dengan itu mereka dapat mengenali Allah secara hakiki, mengenaliNya daripada hasil ciptaanNya, mengenaliNya daripada kesan kekuasaanNya serta merasai hakikat keagunganNya dengan melihat hakikat ciptaanNya. Dengan itu mereka menjadi takut kepadaNya dengan sebenarnya, bertakqwa dengan sebenarnya dan beribadat dengan sebenarnya, bukan dengan perasaan hati yang kabur apabila berhadapan keajaiban alam, tetapi melalui pengetahuan yang halus dan dan ilmu yang langsung. Lembaran-lembaran ini adalah contoh daripada kitab [alam], warna-warna juga merupakan contoh kepada keajaiban penciptaan dan keajaiban keharmonian yang tidak mampu difahami kecuali ulama kitab ini [alam], ulama yang mempunyai ilmu langsung, ilmu yang hati merasai dan bergetar kerananya, di mana dengannya mereka melihat tangan Allah yang mencipta warna, kejadian dan koharmonian alam yang indah tersebut....Sesungguhnya unsur keindahan adalah dimaksudkan dalam rekacipta dan keharmonian alam ini. Antara kesempurnaan keindahan ini ialah sesuatu perkara dapat berfungsi melalui kecantikan". 


\section{Aplikasi Tafakkur Dalam Penyelidikan Sains}

\section{Tafakkur Dalam Islam}

Junaid al-Baghdadi pernah menyebut: "Majlis yang paling mulia dan agung ialah duduk bersama berfikir dalam medan tawhid dan mencium bau makrifah serta minum dari gelas cinta daripada lautan kasih sayang serta melihat dengan sangkaan baik kepada Allah" (al-Ghazali, 2005). Kata Ibn Qayyim (2010): "Tafakkur adalah permulaan dan kunci kepada segala kebaikan... dan ia antara amalan hati yang terbaik serta paling bermanfaat baginya". Dari segi bahasa tafakkur bermaksud berfikir secara logik. Imam al-Ghazali (2005) ketika mendefinisikan istilah ini menyatakannya sebagai 'menghadirkan dua data ke dalam hati bagi melahirkan data yang ketiga", dan beliau memberi contoh berhubung kaedah berfikir ini katanya: "Ada dua cara bagi seseorang yang cenderong kepada yang segera dan mencari kehidupan dunia, dan ingin mengetahui bahawa akhirat lebih wajar dicari berbanding dunia..., Keduanya dengan mengetahui bahawa yang kekal lebih baik dari sementara, dan kemudiannya ia mengetahui bahawa akhirat berkekalan. Maka dia akan mendapat dari dua pengetahuan ini pengetahuan ketiga iaitu akhirat lebih wajar dicari..."

Dalam bahasa penyelidikan hari ini premis pertama tersebut boleh disebut sebagai landasan teori, manakala premis kedua pula merupakan hasil penyelidikan di mana analisa logik deduktif menghasilkan pengetahuan ketiga yang merupakan sebuah kesimpulan. Teknik berfikir sebegini adalah bersifat universal merentasi pelbagai bidang ilmu pengetahuan termasuk dalam usaha mengenali tuhan. Justeru itu tafakkur sebagai salah satu bentuk ibadat adalah merujuk kepada menggunakan kaedah berfikir tersebut bagi mempertingkatkan tingkat keimanan dan tahap marifatullah seseorang (Malik Badri, 2000). Manakala objek tafakkur pula boleh melibatkan apa sahaja perkara atau benda serta apa jua keadaan, sama ada di dunia ini ataupun di akhirat (Malik Badri,
2000). Namun sebarang aktiviti tafakkur perlu dibataskan daripada memasuki zon larangannya iaitu memikirkan zat dan sifat Allah (s.w.t) (alGhazali, 2005).

Bagaimanapun skop perbincangan ini hanya menjurus kepada aplikasi tafakkur dalam aktiviti penyelidikan saintifik berhubung fenomena alam tabii yang merupakan antara bukti kewujudan, keesaan dan keagungan Allah (s.w.t) Rasulullah (s.a.w). Ibn Hibban (1952) meriwayatkan kata-kata Baginda (s.a.w) kepada Bilal (r.a) yang menegur baginda pada suatu hari kerana kehairanan melihat baginda menangis: "... apakah yang dapat menghalang aku dari menangis, sesungguhnya Allah telah menurunkan ke atasku pada malam tadi: "sesungguhnya dalam ciptaan langit dan bumi serta pertukaran siang dan malam ada tandatanda kepada mereka yang berakal". Celakalah orang yang membacanya tetapi tidak berfikir mengenainya"

Menurut Malik Badri (2000), antara pengasas ilmu psikologi Islam moden, proses ibadat tafakkur melalui tiga peringkat aplikasi secara bersambung yang akan membawa peringkat terakhir yang dinamakan sebagai spritual kognitif atau shuhud di mana di peringkat ini akan mewujudkan rasa cinta dan takut pada Allah yang berterusan dalam diri seseorang hamba. Peringkat pertama bermula dengan pencerapan kepada objek tafakkur sama ada secara langsung melalui pancaindera atau tidak langsung berasaskan daya imanginasi. Manakala peringkat kedua pula melibatkan kajian mendalam dengan tujuan memperjelaskan kualiti dan nilai estetika objek tafakkur serta memperlihatkan keindahan, kehebatan dan keajaibannya di yang seterusnya akan membangkitkan kekaguman seseorang penyelidik. Menyusul ke peringkat ketiga ialah aplikasi logik yang bersandarkan nilai keimanan kepada tuhan sebagai landasan teorinya, bagi melakukan lintas langsung melewati sempadan material duniawi serta mengaitkannya dengan Pencipta yang memiliki alam ini. Di sini jiwa seseorang penyelidik akan tersentuh di mana kekagumannya akan berpindah daripada objek 
penyelidikkannya kepada Pencipta objek tersebut. Seterusnya pula, hasil daripada aplikasi ketiga-tiga peringkat ini secara berterusan akan membawa penyelidik menaiki tangga tertinggi untuk menduduki tahap kesedaran spritual syuhūd serta menikmati limpahan macrifatullah dan menjiwai diri seorang ulama.

Seseorang penyelidik yang rutin hariannya sentiasa berpeluang berada dalam nikmat menyelidik yang sentiasa berinteraksi dengan alam tabii, dan kemudiannya mampu pula mengaitkan setiap hasil dapatannya dengan keagungan Allah (s.w.t), jiwanya akan sentiasa dilimpahi kebaikan dan melahirkan peribadi bertakwa. Ibn Qayyim (2010) ketika membuat kesimpulan mengenai kebaikan tafakkur menegaskan: "Secara ringkasnya, asas kepada setiap ketaatan adalah berfikir, begitu pula asal setiap maksiat berlaku apabila meninggalkan berfikir, sesungguhnya syaitan apabila bertemu dengan tanah hati yang kosong akan menyemai padanya pemikiran negatif yang akan melahirkan kehendak dan keazaman dan seterusnya perbuatan, tetapi apabila bertemu dengan tanah hati yang sentiasa sibuk menyemai pemikiran berguna berhubung kenapa ia dicipta, dengan apakah ia disuruh, dan apakah yang disediakan sama ada nikmat yang berkekalan atau azab yang pedih maka ia tidak menemui tempat untuk menyemai"

\section{Aplikasi Tafakkur Terhadap Alam Tabii Menurut al-Ghazali}

Menelusuri pengalaman tafakkur ulama terdahulu memperlihatkan bahawa mereka begitu mendalami nilai kualiti dan estetika alam. Pengetahuan mereka adalah pengetahuan seorang ahli sains atau sekurang-kurangnya mempunyai pengetahuan tentang sains. Di sini perbezaan antara ulama dan saintis adalah objektif kajian di mana seorang ahli sains perubatan contohnya mengkaji untuk mengetahui kaedah merawat sedangkan ulama pula mengkaji bagi memperolehi bukti keagungan penciptanya. Al-Ghazali (2005) yang hidup pada kurun ke sebelas masehi dalam karya agungnya Ihya' Ulum al-Din sewaktu membicarakan teknik bertafakkur, antaranya menjelaskan tafakkur berkaitan kejadian manusia, katanya: "Lihatlah bagaimanakah Allah mencipta tulang-tulang kepala dan bagaimana pula Allah menggabung dan menyusunnya. Ia tersusun daripada lima puluh lima tulang pelbagai bentuk... di antaranya lima untuk cranium, dan empat belas untuk bahagian atas, dan dua untuk bahagian bawah dan selebihnya gigi yang sebahagiannya lebar dan sesuai untuk mengisar, sebahagiannya pula tajam sesuai untuk memotong... dan menyusun tulang belakang daripada bawah bahu hingga hingga tulang sakrum terakhir dengan dua puluh empat tulang spinal, dan menyusun tulang sakrum daripada tiga bahagian berbeza, dan bersambung dari bawahnya tulang coccyx yang juga terdiri dari tiga bahagian... dan keseluruhan bilangan tulang di badan manusia ialah dua ratus empat puluh lapan tulang selain dari tulang kecil-tulang yang terselindung pada celahan sendi.., kemudian ia mencipta peti suara dalam pelbagai bentuk, sempit dan luas, kasar dan lembut, struktur yang padat dan longgar, panjang dan pendek supaya disebabkannya berbeza suara dan tiada yang sama.

Apabila menyentuh berkenaan udara pula beliau menambah: "Kemudian lihat pula pada kelembutan udara dan kemudiannya ketahanan dan kekuatannya bagaimanapun ia ditekan ke dalam air. Bekas air kulit yang dipenuhi udara dapat menahan seseorang yang gagah daripada menenggelamkannya serta melemahkannya... Maka lihatlah bagaimana udara dapat menahan air dengan kekuatannya dalam kelembutannya. Dengan hikmah inilah Allah memegang kapal di atas permukaan air... kerana udara tertahan dari tenggelam di dalam air, maka ia tidak terpisah daripada permukaan dalaman kapal. Jadinya kapal yang berat serta kuat dengan ketumpatannya tergantung dalam udara yang lembut"

Seterusnya beliau menghuraikan berhubung kosmologi: "Lihatlah kecondongan perjalanan matahari di tengah-tengah langit, yang menyebabkan perbezaan musim [kepada] musim panas, musim sejuk, musim bunga dan 
musim luruh. Apabila matahari condong jauh dari pertengahan langit ketika perjalanannya, udara akan menjadi sejuk dan berlakulah musim sejuk. Apabila ianya berada tepat di tengah langit suhu menjadi bersangatan panas dan apabila matahari berada di antara keduanya pula iklim menjadi sederhana....tidak ada mana-mana bintang kecuali demi Allah mempunyai hikmah yang banyak, dari segi kejadiannya, kadarnya, bentuknya, warnanya, kedudukan di langit, jauh serta dekat daripada pusat cakerawala dan jaraknya dengan bintang yang berdekatan dengannya. Bandingkan keadaan tersebut dengan anggota badan anda di mana tidak ada bahagian kecuali mempunyai hikmah yang banyak, namun kedudukan langit lebih hebat... anda tahu betapa besarnya bumi serta keluasan bahagian-bahagiannya di mana seseorang manusia tidak mampu mengelilinginya [dengan teknologi ketika itu]. Para pencerap [ahli kosmologi] bersepakat bahawa nisbah [saiz] matahari berbanding bumi adalah seratus enam puluh kali ganda lebih, manakala bintang yang kamu lihat paling kecil adalah lapan kali ganda, dan yang besarnya pula boleh sampai seratus dua puluh kali ganda bumi. Dengan inilah kita dapat mengukur ketinggian serta jaraknya di mana disebabkan kejauhan ia kelihatan kecil...kemudian lihat pula kepada langit yang segala bintang berada di dalamnya serta betapa besarnya ia. Kemudian lihat pula kepada kelajuan pergerakannya bintang, walaupun anda tidak merasainya apatah lagi kelajuannya, namun sebenarnya dalam satu detik jangka masa tertentu ia telah bergerak sejauh jarak diameternya seratus kali ganda lebih diameter bumi, kerana pergerakkan masa dari ianya mula terbit dilihat dari bumi hingga menjadi sempurna keseluruhannya adalah satu detik tersebut (Ibn Qayyim, 2010)], sedangkan saiznya adalah seratus kali ganda lebih saiz bumi, jadi ia mengorbit dalam satu detik tersebut sejauh seratus kali ganda diameter bumi"

Dalam mengakhiri perbincangannya mengenai tafakkur al-Ghazali (2005) mengajak manusia berpegang kepada doktrin metafizik Ahli Sunnah Wal jamaah apabila berinteraksi dengan fenomena kausal tabii. Ini kerana dalam akidah ahli sunnah wal jamaah, rantaian kausaliti antara sesuatu fenomena dengan fenomena yang lain tidak dilihat sebagai kausaliti hakiki yang membawa kepada wujudnya ikatan wajib antara sebab musabbab secara mutlak. Bahkan segalanya adalah merujuk kepada qada (azali) dan qadar (pelaksanan semasa) Allah (s.w.t) yang mencipta setiap sesuatu dalam sunnahnya yang konsisten. Hakikatnya bagi setiap fenomena yang berlaku, ianya dicipta oleh Allah (s.w.t) dalam bentuk kejadian yang tersendiri tanpa apa-apa pengaruh dari fenomena awal yang dilihat secara zahir sebagai sebabnya, dan Maha Suci Allah Yang Maha Pencipta mencipta setiap kejadian dalam setiap ruang masa sama ada secara langsung ataupun melalui perantaraan malaikatNya. Sehubungan dengan pegangan ini, sebagai kesimpulan al-Ghazali (2005) menegaskan: "Dalam kitab ini [tafakkur] kita memerhatikannya (kejadian) hanya dari sudut ianya sebagai perbuatan Allah. Setiap kejadian yang kita lihat sebenarnya juga dilihat oleh ahli falsafah tabii, di mana pemerhatiannya membawa kepada kesesatan dan penderitaan, manakala bagi mereka yang diberi taufiq apabila memerhatikannya akan membawa pula kepada hidayah dan bahagia. Tidak ada satu zarrah pun sama ada di langit atau di bumi kecuali dengannya Allah (s.w.t) menyesatkan sesiapa yang dikehendaki atau memberi hidayah sesiapa yang dikehendaki. Sesiapa yang memerhatikan perkara ini dari perspektif ianya sebagai perbuatan Allah dan hasil ciptaanNya, akan dapat mengenali keagungan serta kebesaran Allah serta memperolehi hidayah. Sesiap yang memerhatikannya dari perspektif yang hanya terbatas kepada pengaruh fenomena alam antara satu sama lain tanpa hubungannya dengan pencipta sebab, sesungguhnya ia akan menderita, maka kami mohon perlindungan dengan Allah daripada kesesatan." 


\section{Pembinaan Aqidah Tawhid Melalui Penyelidikan Sains}

\section{Tiada Tuhan Melainkan Allah}

Albert Einstein saintis kurun kedua puluh dalam penerokaan sainsnya menemui keyakinan mengenai kewujudan tuhan. Getus beliau dalam gaya bahasa keimanannya: "Perasaan yang paling hebat dan indah yang lahir dari dalam diri manusia adalah hasil penerokaan, berfikir dan mentaakul alam ini, dimensinya, ketersembunyiannya serta kegelapannya. Meraka yang tidak berdetik perasaannya dan tidak berombak emosinya hasil taakulan ini, hidupnya seperti mati. Sesungguhnya ketersembunyian alam, kedalaman dasarnya dan kegelitaan gelapnya, menyembunyikan hikmah yang paling besar dan keindahan yang amat hebat. Hikmah dan keindahan ini tidak dapat diketahui oleh akal kita yang lemah kecuali pada gambaran yang paling asas. Pengetahuan ini adalah asas ibadah bagi makhluk. Agamaku adalah kekagumanku untuk tunduk kepada ruh yang ketinggiannya tanpa sempadan, iaitu kepercayaanku yang mendalam mengenai kewujudan kuasa berakal yang menguasai, yang tampak apabila kita melihat ke dalam alam yang tidak mampu difahami ini..., keimanan ini membentuk dalam diriku makna tuhan" (Mansur Hasabannabi, 1996)

Ini kerana alam merupakan bukti logik (al-dalil al-'aqli) kepada kewujudan dan keesaan Allah, di mana hasil taakulan dialektik logik memberi natijah bahawa adanya alam ini mewajibkan kewujudan penciptanya, dan kesepaduan sistem alam pula (sunnah Allah fi al-kawn) mewajibkan keesaanNya. Lantaran itu kewujudan alam yang penuh keajaiban ini adalah mencukupi bagi membina akidah yang diekspresikan dengan kalimah Lailahaillallah. Di sini sains tabii merupakan antara bidang yang menempatkan pengkajinya untuk sentiasa berinteraksi dengan dalil-dalil kewujudan dan keesaan Allah, di mana mengenali Allah adalah kemuncak dapatannya. Firman Allah (s.w.t) berhubung perkara tersebut: Kami akan perlihatkan kepada mereka tanda- tanda kekuasaan Kami di merata-rata tempat (dalam alam Yang terbentang Luas ini) dan pada diri mereka sendiri, sehingga ternyata jelas kepada mereka Bahawa Al-Quran adalah benar. belumkah ternyata kepada mereka kebenaran itu dan belumkah cukup (bagi mereka) Bahawa Tuhanmu mengetahui dan menyaksikan tiaptiap sesuatu? (Al-Quran $41: 53$ )

Namun hari ini penghayatan muslim dikaburkan oleh dominasi ideologi kufur darwinisma melalui doktrin evolusinya yang melihat fenomena alam tidak lebih daripada hasil interaksi rawak tenaga berdasarkan prinsip keberangkalian, melalui mekanisma yang dikenali sebagai pilihan tabii, yang mana hingga hari ini menjadi intipati metafizik barat (Mansur Hasabannabi,1996). Justeru itu penolakan teori ini menggunakan kaedah yang sama berasaskan juga kepada prinsip keberangkalian adalah cukup mustahak bagi membina asas aqidah yang bersih.

Untuk itu kita boleh merujuk kepada saintis mereka sendiri yang percaya bahawa kewujudan alam tabii adalah hasil adanya intelligent design dan bukan pilihan tabii. Charles Eugene contohnya, pakar matematik Switzland berjaya menolak teori kewujudan berasaskan pilihan tabii melalui aplikasi prinsip keberangkalian. Beliau menjelaskan bahawa kemungkinan (result of chance) kewujudan sesuatu sel protien hasil daripada gabungan 40,000 atom yang hanya daripada lima unsur iaitu karbon (c), hidrogen (h), nitrogen (n), oksigen (o) dan sulfur (s), secara pilihan tabii, sedangkan jumlah keseluruhan unsur ialah sembilan puluh dua (92) unsur, di mana kelima-lima unsur tersebut tertarik sesama sendiri dengan kuasa elektromegnetik ialah 1:10160 (Mansur Hasabannabi,1996). Selain itu jika dihitung keberangkalian asid amino tersusun bagi membentuk sesuatu molekul protein pula, satu molekul protein sederhana yang merangkumi 288 asid amino boleh tersusun kepada 10300 bentuk yang berbeza. Oleh kerana bagi membolehkannya berfungsi untuk kebaikan tubuh, ia perlu tersusun dalam satu bentuk sahaja, peluangnya untuk terbentuk sebegitu melalui mekanisma pilihan tabii ialah 
1:10300, sedangkan dalam matematik kadar keberangkalian yang lebih kecil daripada 1:1050 adalah bersamaan dengan kemungkinan sifar (Harun Yahya,1999). Tambahan pula jangka masa yang diperlukan untuk mewujudkan satu sel protein secara pilihan tabii adalah selama 10243 tahun (Mansur Hasabannabi, 1996) sedangkan umur alam baru menjangkau lima belas bilion tahun. Justeru itu jelas bahawa alam ini ada penciptan yang menyusun aturnya, Ia wujud dan esa dan kita bersaksi bahawa tiada tuhan melainkan Ia.

\section{Muhammad Pesuruh Allah}

Perutusan para rasul membawa berita langit kepada umatnya, seringkali diperkukuhkan dengan mukjizat bukti kebenarannya risalah mereka. Sebagaimana definisinya, mukjizat merujuk kepada fenomena hebat yang mengatasi apa sahaja kemajuan dan pencapaian manusia di zamannya. Oleh itu ianya perlu seiring dengan perkembangan masa dan zaman. Mukjizat Musa (a.s), di era sihir menduduki takhta zaman diperlihatkan melalui keupayaan tongkat berubah menjadi ular dan menelan semua ular sihir ahli sihir diraja Firaun sebagaimana dirakam Allah (s.w.t) dalam Al Quran (20 : 65-70); (7 : 105-120); (10: 79-82) dan (26 : 38-48). Manakala kerasulan Isa (a.s), pada waktu ilmu perubatan mendapat tempat, Allah (s.w.t) memperkukuhkan baginda dengan keupayaan menyembuhkan penyakit buta dan sopak yang belum boleh diubati pada masa itu, mencipta burung dari tanah serta menghidupkan orang mati dengan izin Allah, mengalahkan keangkuhan umatnya dalam bidang perubatan sebagaimana dirakam Allah (s.w.t) Al Quran (3 : 49) dan (5: 110). Begitu juga dengan kerasulan junjungan besar kita Muhammad (s.a.w), yang diperkuatkan dengan mukjizat besar melalui wahyu al-Quran dan al-Sunnah, pada masa umat baginda terkenal dengan penguasaan bahasa dan sastera, mencabar mereka yang untuk mencipta seumpama al-Quran sebagaimana diperhatikan dalam Al Quran (2 : 23-24) dan (10:38).

Mukjizat al-Quran bermaksud al-Quran sendiri dapat membuktikan ianya adalah wahyu Allah. Pembuktian ini seterusnya membuktikan bahawa sesiapa yang menerimanya adalah pesuruh Allah. Oleh itu, seiring dengan kedudukan Baginda (s.a.w) sebagai nabi akhir zaman dan perutusannya mencakupi keseluruhan umat manusia, dalam keadaan pencapaian manusia sering berubah-ubah mengikut perkembangan masa, maka wahyu al-Quran dan al-Sunnah dilengkapi dengan ciriciri abadi yang berkeupayaan mengiringi dan menangani setiap perubahan, begitu juga dengan nilai-nilai mukjizat keduanya. Kini apabila sains dan teknologi ternobat sebagai pencapaian tertinggi umat Muhammad (s.a.w), ianya mencetuskan dimensi baru mukjizat al-Quran dan al-Sunnah, melahirkan bukti-bukti baru kerasulan Baginda agar mencabar masyarakat zaman ini untuk tunduk memperakuinya. AlQuran mengandungi banyak ayat-ayat yang boleh dikategorikan sebagai ayat saintifik. Sebahagiannya secara jelas memperkatakan berkenaan fenomena saintifik empat belas kurun dahulu yang kebenarannya terbongkar pada hari ini dengan pengunaan pelbagai peralatan canggih.

Berhubung dengan kosmologi Mansur Hasabannabi (1996) menjelaskan antaranya dalam Al Quran (21:30) yang menjelaskan berhubung awal kejadian kosmos yang dikenali sebagai big bang, Al Quran (51:47) mengenai fenomena keadaan langit yang semakin berkembang, Al Quran (51:49) mengenai setiap ciptaan adalah berpasangan, (13:2) mengenai pergerakan jirim kosmos, Al Quran (41:12) mengenai kejadian kosmos bermula dalam bentuk gas (nebula), Al Quran (21:104) mengenai kehancuran kosmos secara proses berbalik, Al Quran (31:10) dan Al Quran (13:2) yang menjelaskan struktur cakerawala dengan tiang yang tak dapat dilihat yang dikenali sebagai tarikan graviti universalAl Quran (32:5) yang mengukur kelajuan cahaya berasaskan persamaan matematik serta kewujudan benda gelap yang tidak bertindak balas dengan cahaya, Al Quran (10:61) dan (34:3) mengenai wujud sesuatu yang lebih kecil dari atom, Al Quran 
(81:2), (77:8) dan (53:1-2), (55:37) mengenai keadaan bintang di akhir hayatnya, Al Quran (18:25-26) mengenai perbezaan antara tahun lunar dan tahun solar.

Manakala ayat-ayat berkenaan bumi pula, Adnan Syarif (2000) menulis berkaitan ayatayat dalam Al Quran (2:29), (41:11-12), $(65: 12)$ dan (78:12) mengenai tujuh lapisan langit yang melindungi bumi, (65:12) mengenai pembahagian bumi kepada tujuh lapis, Al Quran (86:12) mengenai pergerakkan kerak bumi, (15:19), (27:15), dan (31:10) mengenai gunung yang menyeimbangkan kerak bumi, Al Quran (86:11) dan (21:32) mengenai medan magnet bumi dan peranannya, Al Quran (51:7) mengenai lubang pada lapisan langit untuk menyahkeluar gas-gas merbahaya dari ruang udara, Al Quran (25:53) dan (55:19-20) mengenai penghadang kimia yang menghalang ciri-ciri dua lautan daripada bercampur dan Al Quran (24:40) mengenai lapisan ombak laut dan had cahaya menembusi air laut, dan sebagainya.

Beralih kepada ayat berhubung kejadian manusia, kaitan antara proses kejadian dan perkembangan manusia dengan al-Quran boleh diperhatikan antaranya dalam Al Quran (32:8), (75:37) dan (53:45-46) mengenai asal kejadian daripada air mani; Al Quran (22:5), (23:12-14), (39:6) mengenai peringkat kejadian manusia di dalam Rahim (Abd Majeed Zindani, E. Marshal Johnson, Gerald C. Georinger, Joe Leigh Simpson, Keith L. Moore, Mustafa A. Ahmad \& T. V. N. Persaud, 2000). Prof Keith L. Moore dalam kesimpulanya ketika menulis mengenai terma Al Quran berkaitan klasifikasi perkembangan embrio menegaskan: "Terma al-Quran menjelaskan kejadian yang berlaku dalam setiap peringkat perkembangan dengan tepat. Ianya menjelaskan kejadiankejadian secara kronologi dan menggambarkan perubahan bentuk embrio dengan tepat, termasuk perubahan morfologi pada setiap peringkat. Nabi Muhammad (s.a.w) tidak mungkin mengetahui fakta ini pada kurun yang ketujuh, kerana kebanyakkannya hanya ditemui pada kurun yang ke dua puluh. Ilmu ini hanya boleh disampaikan kepada Nabi melalui Tuhan, Pencipta yang Maha Mengetahui yang memiliki ilmu sepenuhnya berkaitan perkembangan manusia dan seluruh cakerawala. (Abd Majeed et al., 2000)

Maka lantaran itu tiada ekspresi yang lebih jelas selepas segala pengetahuan tersebut selain dari pengakuan bahawa Muhammad adalah Rasulullah.

\section{Kesimpulan}

Sains merupakan alat yang dicipta oleh Allah (s.w.t) untuk kegunaan manusia. Manusia yang bersyukur akan menggunakannya bagi membina hubungannya dengan tuhannya di samping hubungannya sesama manusia. Pendidikan yang berpusatkan agama sebagai teras pembangunannya akan lebih mudah dan cepat untuk berjaya dalam pembangunan modal Insan. Ini kerana keupayaannya melahirkan insan dengan ketiga-tiga kemahiran IQ, EQ dan SQ, secara serentak tanpa perlu kepada program-program berasingan bagi membina setiap fakulti tersebut.

\section{Rujukan}

Abd Majeed Zindani, E. Marshal Johnson, Gerald C. Georinger, Joe Leigh Simpson, Keith L. Moore, Mustafa A. Ahmad \& T. V. N. Persaud (2000). Human Development As Described in The Quran and Sunnah. Makkah: Muslim World League.

Adnan al-Syarif (2000). Min Ulum al-Ard alQuraniyah. Beirut: Dar al-Ilm Li al-Malayin.

Al-Alusi, Syihab al-Din (2000). Ruh al-Ma'ani fi Tafsir al-Quran al-Azim wa Sab'u al-Mathani. Beirut: Dar al-Ihya’ al-Turath al-Arabi

Al-Andalusi, Abu Hayyan (1993). Tafsir al-Bahr al-Muhit. Beirut : Dar al-Kutub al-Ilmiyyah.

Al-Baqqai, Burhan al-Din (t.t.) Nazam al-Durur fi Tanasub al-Ayat wa al-Suwar. Kaherah : Dar 
al-Kutub al-Ilmiyyah.

Al-Ghazali (2005) Ihya' 'Ulum al-Din. Beirut

: Dar Ibn Hazm.

Al-Razi, Fakh al-Din (2000). Mafatih al-Ghayib,

Beirut: Dar al-Kutub al-Ilmiyyah.

Al-Syahrastani. (2009.) al-Milal wa al-Nihal, Beirut: Muassasah al-Risalah Nasyirun.

Al-Tabari, A. J. (1998). Jami` al-Bayan fi Ta’wil al-Quran. Bayrūt: Dar al-Kutub al-Ilmiyyah.

Al-Ya'qoobi. (2002.) Tarikh al-Ya'qoobi. Beirut: Dar al-Kutub al-Ilmiyyah.

Hairudin Harun. (1992.) Dari Sains Yunani Kepada Sains Islam, Kuala Lumpur: Universiti Malaya.

Harun Yahya. (1999). The Evolution Deciet. United Kindom : Ta-Ha Publisher.

Ibn 'Abari. (2007). Tarikh Mukhtasar al-Duwal. Beirut : Dar al-Masyriq.

Ibn Abi Usaibi'ah. (2016). 'Uyun al-Anbiya Fi Tabaqat al-Atibba'. Abu Dhabi: Dar al-Kutub al-Wataniyah.

Ibn al-Kindi. (2009). Fadail Misr al-Mahrusah. Maktabah al-Khaniji.

Ibn Hibban. (1952). Sahih Ibn Hibban. Mesir : Dar al-Maarif
Ibn Kathir. (1999). Tafsir al-Quran al-Azim. Beirut: Dar al-Kutub al-Ilmiyyah.

Ibn Khaldun. (2001).. Tarikh Ibn Khaldun Beirut : Dar al-Fikr

Ibn Qayyim al-Jawziyah. (2010). Miftah Dar al-Sa'adah. Makkah: Dar Alim al-Fawa'id.

Kevin Van Bladel. (2009). The Arabic Hermes. Oxford University Press

Malik Badri. (2000) Contemplation, An Islamic Psycospiritual Study. Herndon : The International Institute of Islamic Thought.

Mansur Hasabannabi. (1996a) al-Kawn wa alI'jaz al-'Ilmi. Kaherah : Dar al-Fikr al-'Arabi.

Mansur Hasabannabi. (1996b) I‘jaz al-Quran Fi al-Afaq al-Zaman wa al-Makan. Keherah: Dar al-Fikr al-Arabi.

Maqdisi. (t.t) al-Bad'u wa al-Tarikh. Port Said : Maktabah al-Thaqafah al-Diniyah.

Sayyid Qutb. (1998). Fi Zilal al-Quran. Kaherah: Dar al-Syuruq.

T. J. De Bour. (t.t.). Tarikh al-Falsafah alIslamiyyah, Muhammad Abd Hadi Abu Raidah (Terj). Beirut: Dar al-Nahdah al-Arabiyyah. 